\title{
Does Investment in Schooling Raise National Income? Evidence from Cross-Country Studies
}

¿Invertir en la educación sube el ingreso nacional?

Evidencia de los estudios entre países

Theodore Richard Breton*

Fecha de recepción: 24/03/2011

Fecha de aceptación: 22/05/2011

* Doctor en economía, George Mason University y Magister en economía, London School of Economics. Actual coordinador de la Maestría en Economía. Docente y Coordinador investigación y publicación en el área de educación y crecimiento (macroeconomía) y el efecto de la educación en los salarios de los obreros (microeconomía) de la Universidad EAFIT, Medellín-Colombia.

tbreton@eafit.edu.co 


\title{
100
}

Does Investment in Schooling Raise National Income?

Evidence from Cross-Country Studies

THEODORE RICHARD BRETON

\begin{abstract}
The economics literature identifies three effects of schooling on national income; the direct effect on the earnings of the workers who receive the schooling and the external effects on workers' earnings and on physical capital due to schooling's spillover effect on the productivity of these other factors of production. This paper reviews the estimates of the income elasticity of these three effects in the literature and finds that the evidence supports an elasticity of 0.34 . The associated marginal rates of return on national investment in schooling in 2000 are found to average about 12 percent in countries with high levels of schooling and about 25 percent in countries with low levels of schooling.
\end{abstract}

\section{Key words}

Human Capital, Schooling, Education, Physical Capital, National Income, Economic Growth

\section{Resumen}

La literatura económica identifica tres efectos que tiene la educación sobre el ingreso nacional; el efecto directo en los ingresos de los trabajadores que reciben cierto nivel de educación, el efecto externo en los ingresos de estos y el efecto en el capital físico debido al impacto que tienen los estudios sobre la productividad en estos factores de producción. Este artículo revisa los cálculos encontrados en la literatura de la elasticidad de los ingresos con estos tres efectos y encuentra que la evidencia confirma una elasticidad de 0,34. Las tasas marginales de retorno de la inversión nacional en educación en el 2000 muestran un promedio de 12\% en los países con un nivel alto de educación y aproximadamente $25 \%$ en los países con niveles bajos de educación.

\section{Palabras clave}

Capital Humano, Estudios, Educación, Capital Físico, Ingreso Nacional, Crecimiento Económico.

Clasificación JEL: E23, F43, I21, 011, 015, 047. 


\section{Introduction}

How much does investment in schooling raise national income? Over the last 20 years the effect of schooling on national income has been one of the most controversial issues in the fields of economic growth and economic development. Innumerable cross-country empirical studies have been carried out to ascertain the magnitude of the effect, and until recently these studies had failed to reach any consensus. While some studies indicated that additional schooling has a large, positive effect on national income, other studies found no effect, or a negative effect.

Why have the studies in the literature found such different effects? A consensus seems to be emerging that the studies that found small or negative effects suffered from a series of data and statistical estimation problems. In the more recent studies that have used better data and addressed the identified methodological problems, the estimated effect of schooling on national income is quite large, particularly in cross-sectional studies and in lower-income countries.

This article explains the processes by which additional schooling appears to raise national income, including the external effects on the productivity of physical capital and unschooled labor. The article then summarizes the historic estimates of the effect of schooling on national income in the literature, summarizes the current explanations for the lack of consistency in these estimates, and explains why the latest estimates seem to have more validity. Finally, the article presents the marginal product of human capital from schooling for 61 countries in 2000 using data from one of the most recent studies and discusses the implications of these estimates for public policy on investment in schooling.

\section{Methodological considerations}

The starting point for any economic analysis is the observation of economic activity and the creation of a conceptual model that may explain that activity. Economists have observed the growth of national economies and hypothesized that output is determined by a series of factors, including the number of workers $(L)$, the skill or human capital of these workers $(\mathrm{H})$, the physical capital (land, structures, or equipment) employed $(\mathrm{K})$, and other national characteristics that affect the productivity $(A)$ of these factors. The most 
Does Investment in Schooling Raise National Income?

Evidence from Cross-Country Studies

THEODORE RICHARD BRETON

widely-used mathematical model of national output using these factors in the literature is a Cobb-Douglas production function:

1) $Y=(K)^{\alpha}(H)^{\beta}(A L)^{1-\alpha-\beta}$

Due to this model's multiplicative structure, it exhibits what has been termed "capitalskill complementarity," which means that increases in either physical capital or human capital raise the marginal product of the other capital factor. Implicitly the increase in one capital factor has a direct effect on national output and an indirect effect that occurs through its effect on the other factors. For example, suppose a private firm has a personal computer, which is a form of physical capital (K), and two employees (L) of which one has some capability $(\mathrm{H})$ to utilize this computer. If the one employee is trained to make better use of this computer, his human capital increases, which makes him more productive and also makes the computer more productive. In addition, this employee may be able to use the computer to make the other employee (L) more productive. In this way, the increase in one employee's human capital raises the marginal productivity of all three factors of production in the economy.

Although human capital can be created through informal training, in a modern economy it is created primarily through the formal schooling process. In the remainder of this article, $\mathrm{H}$ refers only to the portion of human capital created through formal schooling.

Figure 1 shows the dynamic process by which increased schooling affects national income in the model of national output in Equation (1). The effects of increased schooling are shown with a series of arrows, which indicates the direction of causality. The direct effect (1) is shown with a solid line, while three external or indirect effects $(2,3$, and 4$)$ are shown with dotted lines.

An increase in schooling raises national income through three channels. First, it raises the nation's human capital, which makes the workers receiving the schooling more productive. Second, the workers who have received the schooling interact with and manage other workers, making them more productive. Third, the greater skill of the schooled workers makes physical capital more productive. These three effects combine to increase national output/national income. The higher national income then leads through private and political decisions to a fourth effect, which is an increase in a nation's investment in schooling. 
Figure 1

Model of National Production

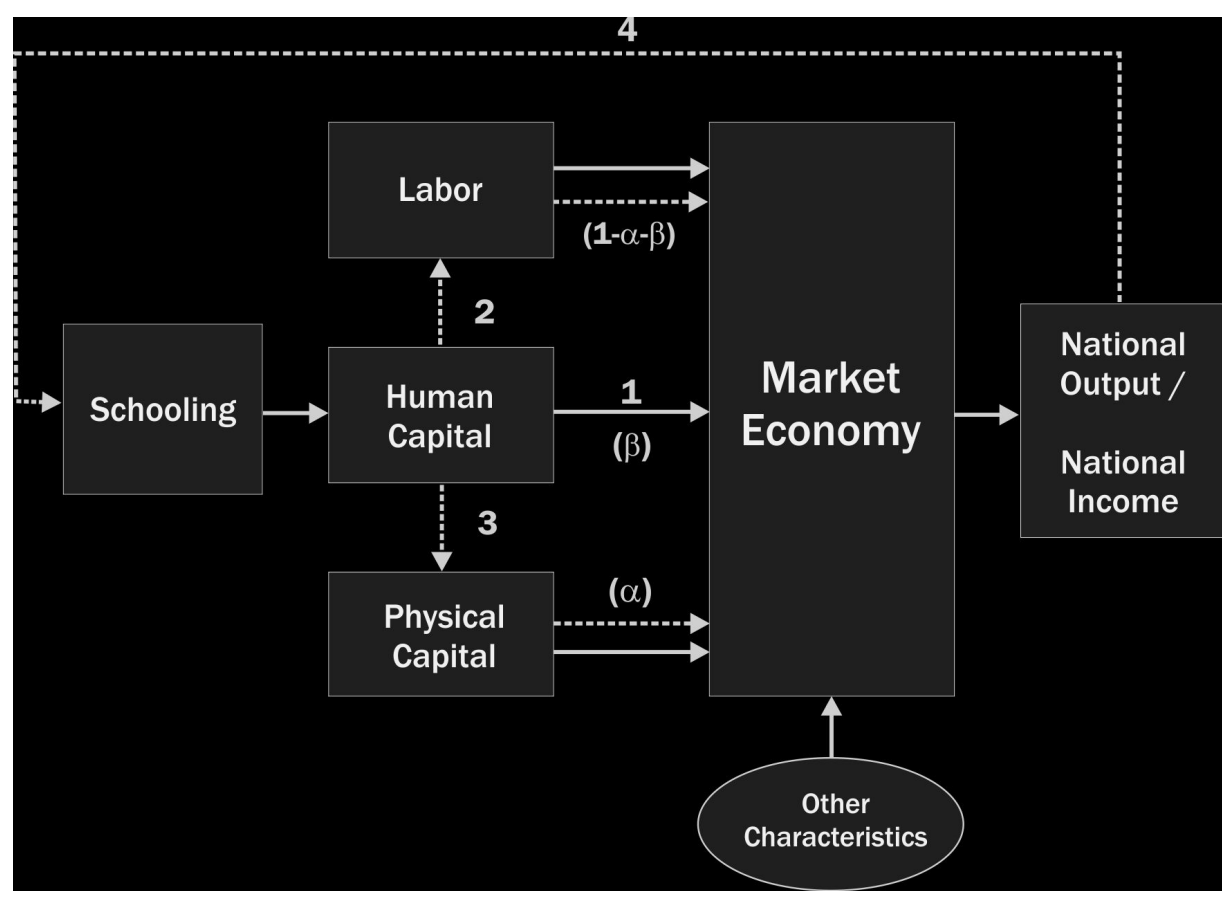

The key aspect of the model is that schooling increases national productivity in part through external ${ }^{1}$ effects. In other words, as Lucas (1990) postulated, there is an external "spillover" effect of schooling which causes national income to increase by more than the increase in the earnings of the worker who received the additional schooling.

The direct, positive effect of schooling on a worker's subsequent earnings is welldocumented in studies performed throughout the world (Psacharopoulos \& Patrinos, 2004). This is the effect labeled " 1 " in the figure. If there were no other effects, a nation's investment in schooling would be expected to raise national income by the aggregate increase in the earnings of all of its schooled workers.

The second effect, labeled "2" in the figure, is the external effect that schooling has on the productivity of workers who did not receive the schooling, which further increases regional and national income. Empirical studies of the external effect of schooling on the incomes of other workers in cities and regions within countries provide evidence

1 Economists define an "external" effect as one that does not result in any cost or benefit to its source in the marketplace. 
Does Investment in Schooling Raise National Income?

Evidence from Cross-Country Studies

THEODORE RICHARD BRETON

for this external spillover effect. Acemoglu and Angrist (2001) found external effects of schooling on the personal income of other workers in states within the U.S. Moretti (2004) found external effects of schooling on the personal income of other workers in U.S. cities. Liu (2007) found external effects of schooling on the personal income of other workers in cities in China. Basu, Narayan, and Ravallion (2002) found external effects of literacy on the personal income of illiterate family members in Bangladesh. Breton (2010a \& 2010b) presents evidence that there are external effects of human capital from schooling on income across countries at the national level.

The external effects quantified in these various studies could occur through numerous pathways:

- Workers who are more educated may train other workers on the job, who then become more productive in a manner not related to their own formal schooling

- Countries with a more educated work force may adopt new technology more rapidly.

- Educated parents may provide additional education to their children in the home setting, who then become more productive later as workers.

- More educated citizens may adopt more hygienic or other public health practices that reduce the level of morbidity and mortality of all workers and make them more productive on the job.

- More educated citizens may demand more enlightened public policies from their political leaders, resulting in better infrastructure, less corruption, better institutions, and other practices that raise national productivity.

- More educated citizens may experience less unemployment, commit fewer crimes, and impose fewer costs on society.

The third effect, labeled " 3 " in the figure, is the external effect that human capital has on physical capital productivity, which further increases national income. This is the result of capital-skill complementarity, which has been documented in many countries. FitzRoy and Funke (1995) find evidence of this effect between white collar workers and physical capital in West German manufacturing. Grier (2005) presents evidence that increased human capital raises investment in physical capital in sub-Saharan Africa. Lopez-Bazo and Moreno (2008) find a strong effect of human capital on physical capital productivity 
in Spain. Yasar and Morrison Paul (2008) find evidence that human capital raises physical capital productivity in Turkish manufacturing. Chi (2008) presents evidence that greater human capital raises investment in physical capital in China.

The fourth effect shown in the figure is the reverse effect from the level of income to the level of schooling. Empirical studies in the literature indicate that individuals and nations have a positive income elasticity of demand for schooling, i.e., when they obtain more income, they spend more on schooling. Numerous studies have found this effect in many countries, including Rubinfeld and Shapiro (1989) in the U.S., Maitra (2003) in Bangladesh, Song, Appleton, and Knight (2006) in China, and Glewwe and Jacoby (2004) in Vietnam. The existence of this reverse effect from national income to schooling, occurring simultaneously with the effects from schooling to national income, greatly complicates the problem of accurately estimating the magnitude of the effects of schooling on national income.

Most economists now agree that schooling and national income are related conceptually in the four ways shown in Figure 1. What remains at issue is the magnitude of the various effects and the importance of other characteristics of an economy that may affect the productivity (a) of the three main factors of production.

Researchers have included an array of different variables to represent these countryspecific characteristics, and there is no consensus about their relative importance for national productivity. These characteristics include institutional quality, the structure of the economy (e.g., openness to FDI, international trade, or global capital flows), climate, geography, political stability, and public health. A nation's productivity also is affected by world technological progress over time and by increases in human capital resulting from informal schooling (e.g., private tutoring, and on-the-job training). These influences are not explicitly represented in the model in equation (1), so they implicitly remain as crosscountry differences that affect national productivity (A).

In a Cobb-Douglas structure the exponent on a factor of production measures the marginal effect on income of increasing that factor of production, while holding the other factors constant. In calculus this is known as the partial effect. The exponent $\beta$ on human capital $(\mathrm{H})$ measures the effect of increased schooling on national income. Importantly, this effect includes both the direct effect of schooling on the earnings of the worker who received the schooling and the external effects of schooling on national 


\section{6}

\section{Does Investment in Schooling Raise National Income? Evidence from Cross-Country Studies \\ THEODORE RICHARD BRETON}

output operating through the unschooled worker and physical capital channels (labeled 1, 2 and 3 in Figure 1).

The model in equation (1) is homogeneous of degree 1 because the three exponents on the three factors of production add up to one. This structure is conceptually appealing for a model of national output because it guarantees constant returns to scale, i.e., if all the factors of production are increased by a common multiple, output increases by the same multiple. This relationship ensures that the size of a country does not determine its income per worker. With this property small countries and large countries with the same proportions of factors of production have the same income per worker, a relationship that seems to accord with reality. This structure has several very convenient mathematical properties:

- First, in a market economy the share of national income that accrues to each factor of production is equal to the exponent on that factor. ${ }^{2}$ So the share of national income accruing to physical capital (K) is $\alpha$. Bernanke and Gurkaynak (2001) estimate that this share is consistently about 0.35 across countries. The implication is that the rest of national income (1- $\alpha)$, or about 65 percent of it, accrues (pre-tax) to workers.

- Second, the model in equation (1) can be transformed into a model of national income per worker $(\mathrm{Y} / \mathrm{L})$ that is a function of the average human capital per worker, the average physical capital per worker, and any other country-specific characteristics:

(2) $Y / L=(H / L)^{\beta}(K / L)^{\alpha} A^{1-\alpha-\beta}$

- Third, the log version of this model is a linear function that can be estimated statistically using linear regression to determine the magnitudes of $\alpha$ and $\beta:^{3}$

(3) $\log (Y / L)=\beta \log (H / L)+\alpha \log (K / L)+(1-\alpha-\beta) \log (A)$

Many researchers have estimated the income model in equation (3) using cross-country data, either at one point in time or over time using panel data. The model also has been

2 This result occurs because in a competitive market the wage or return on capital is equal to the marginal product of the factor of production, which is determined by the exponent on each factor of production.

3 Since this income model is in "log-log" form, the coefficients $\alpha$ and $\beta$ are known as income "elasticities". 
estimated in many different mathematical forms, including as a rate of growth in income per worker, as a change in income per worker over a time period, and as a function of the share of GDP expended on physical capital and human capital. Estimation of the model in some of these forms yields estimated coefficients that are not equal to $\alpha$ and $\beta$, but their implied values can be calculated from their estimated coefficients.

\section{A Review of the Estimates of $\beta$ in the Literature}

Each study in the literature typically includes numerous estimates of the effect of schooling from models that include variables for various country-specific characteristics, and some contain estimates developed with more than one statistical technique. Figure 2 presents estimates of $\beta$ either taken directly from the empirical literature over the period from 1992 to 2011, or calculated by the author from estimates of reduced forms of the model in equation (3). The particular estimates shown are those from the model(s) that are most similar to the model in equation (3) and in most cases are the one or two principal estimates highlighted in the study. The Appendix provides the coefficients estimated in the literature and the calculated, implied values of $\alpha$ and $\beta$.

A review of the results in Figure 2 shows that from 1994 until 2001, most cross-country statistical studies rejected the hypothesis that schooling has a large, positive effect on national income. After 2001, however, researchers obtained larger, positive estimates of $\beta$ in the 0.21 to 0.34 range. But as Levine and Renelt (1992) observed, "Given that over 50 variables have been found to be significantly correlated with (economic) growth in at least one regression, readers may be uncertain as to the confidence they should place in the findings of any one study" (p. 942).

Given the large discrepancies in the effects of schooling found across studies, it is reasonable to ask whether the more recent estimates of $\beta$ are more reliable than the earlier estimates. As discussed below, it now appears that that the negative and small positive estimates of $\beta$ obtained during 1994-2001 were biased due to measurement error in the schooling data and other estimation problems. Since these problems have been addressed in the more recent studies, the more recent results are likely to be more reliable. 
Does Investment in Schooling Raise National Income?

Evidence from Cross-Country Studies

THEODORE RICHARD BRETON

Figure 2

Estimates of $\beta$ in the Literature

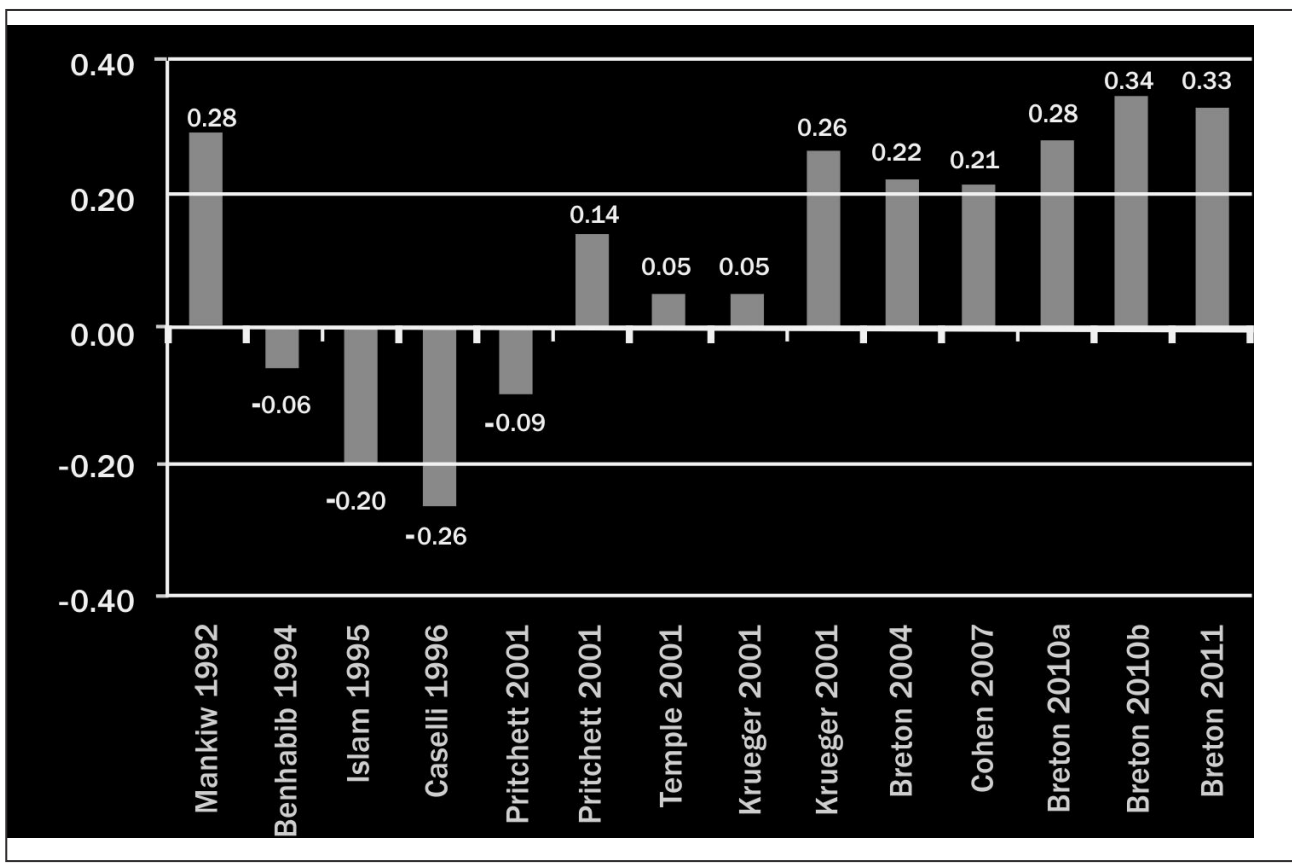

Estimation of the income model in equation (3) only became possible once researchers had assembled a set of cross-country data for income per worker, physical capital per worker, human capital per worker, and other characteristics affecting national productivity. Summers and Heston (1991) facilitated this process when they published the Penn World Table (Mark 5), which included a complete cross-country set of annual data on national income and investment in physical capital, adjusted for purchasing power parity across countries. The initial Mark 5 data set provided data from 1950 through 1985, and the most recent data set (version 7.0) provides data through 2009 (Heston, Summers, \& Aten, 2011). Most studies estimating the effect of schooling on national income have used these data sets.

Unfortunately, the Penn World Table does not include data on schooling, so researchers have had to obtain these data elsewhere. Mankiw, Romer, and Weil (1992) used UNESCO data on cross-country levels of secondary school enrollment as a proxy for the national rate of investment in schooling, but their results were criticized because their human capital variable did not include primary and university schooling (Dinopoulos \& Thompson, 1999). All but one of the subsequent studies published between 1994 and 2001 used cross-country data on the average years of schooling attainment to represent 
the national stock of human capital. The studies published from 1995 to 2001 used various versions of Barro and Lee's (1993; 2001) data on average schooling attainment in the population over age 15 or over age 25. Pritchett (2001) created his own estimate of the human capital stock using the discounted value of workers' earnings.

In the 1994-1996 studies, researchers used the log of average schooling attainment to represent $\log (\mathrm{H} / \mathrm{L})$, and they obtained negative estimates of $\beta$. Subsequently, researchers realized that the normal Mincerian methodology in micro studies of workers' earnings is to relate $\log (\mathrm{Y} / \mathrm{L})$ to years of schooling rather than to the log of this value. When they used average schooling attainment to represent $\log (\mathrm{H} / \mathrm{L})$ rather than $\mathrm{H} / \mathrm{L}$, they began to get positive estimates of the effect of schooling on national income. ${ }^{4}$ With this change in the form of the human capital variable, the estimated coefficient on average schooling attainment ceased to be an estimate of $\beta$, but the implied values of $\beta$ in these studies are very small.

Krueger and Lindahl (2001) made a major contribution to this literature when they determined that the small estimates of $\beta$ were due to attenuation bias resulting from measurement error in the schooling data. Since Pritchett (2001), Temple (2001), and others used a "fixed effects" statistical technique and panel data with five-year periods to estimate most of their models, their estimates implicitly measured only the effect of changes in schooling within countries over five-year periods. ${ }^{5}$ Krueger and Lindahl (2001) showed that over such a short period the measurement error in the schooling data overwhelms the small changes in the data, biasing the statistical estimates of the effect of schooling toward 0 . As an example of this problem, Pritchett (2001) obtained an implied value of $\beta=0.14$ when he examined the effect of schooling on national income across countries in one year, but he obtained an implied value of $\beta=-0.09$ when he examined the effect of differences in schooling within countries over five years. These estimates are both shown in Figure 2.

4 A graph of cumulative investment in schooling and average schooling attainment shown in the appendix indicates that $\log (\mathrm{H} / \mathrm{L})$ is best represented by average schooling attainment, not log (average schooling attainment).

5 Researchers sometimes add a dummy variable for each country to their income model to control for any unidentified, country-specific, non-varying productivity effect. This is called a "fixed effects" statistical technique. The drawback of this approach is that it eliminates consideration of the cross-country variation in income and schooling from the regression results, and this cross-country variation is much larger and less affected by data measurement error than the variation within a country over a short period of time. 


\section{0}

\section{Does Investment in Schooling Raise National Income? Evidence from Cross-Country Studies \\ THEODORE RICHARD BRETON}

Krueger and Lindahl (2001) obtained a small implied value of $\beta=0.05$ when they examined the effect of the change in schooling attainment on (log) national income within countries over 20 years, but they also obtained a value of $\alpha$ (the share of physical capital) that was much higher than the value estimated from micro studies. When they forced the estimate of $\alpha$ to 0.35 , the share of national income actually accruing to physical capital, they obtained the much higher implied value of $\beta=0.26$. They concluded that the high correlation between the human capital (schooling) data and the physical capital data, and perhaps the problem of reverse causality, must be biasing the effect of schooling downward in the unconstrained model.

Breton (2004), Cohen and Soto (2007), Breton (2010a; 2010b), and Breton (2011) subsequently estimated the effect of schooling on national income using four new schooling data sets. Cohen and Soto (2007) and Breton (2011) used a new data set on average schooling attainment that has less measurement error than the Barro and Lee (2001) data. Breton (2004) and Breton (2010a; 2010b) used new data sets for the cumulative investment in schooling to represent the stock of human capital. These researchers also used other forms of the model in equation (3) to reduce the correlation between human capital and physical capital in the regressions. Breton estimated the effect of human capital across countries in various years, while Cohen and Soto estimated the effect within countries over the 1960-90 period. With these changes in the earlier methodologies, and in some cases with the use of instruments for human capital, the researchers obtained much larger implied values of $\beta$ in the 0.21 to 0.33 range.

Within this group of estimates, arguably the more accurate estimates are those in which the estimate of $\alpha$ is closer to independent estimates of its value, which as mentioned earlier, indicate that $\alpha \approx 0.35$. Since a nation's levels of physical capital and human capital are highly correlated, if the estimate of the effect of one form of capital in equation (3) is biased upward, the estimate of the effect of the other form is likely to be biased downward (Mankiw, 1995). As a result, the least biased estimates of $\beta$ are likely to be those from regressions that obtain an estimate of $\alpha \approx 0.35$. Figure 3 shows the estimates of $\alpha$ that accompanied the estimates of $\beta$ shown in Figure 2. The earlier studies with low or negative estimates of $\beta$ all had estimates of $\alpha$ that were considerably larger than 0.35. These are the studies shown to have had methodological problems. In contrast, in the three recent studies with regressions that yielded an implied value of $\alpha$ $\approx 0.35$, the implied values of $\beta$ are between 0.28 and 0.34 . 


\section{Figure 3}

\section{Estimates of $\alpha$ and $\beta$ in the Literature}

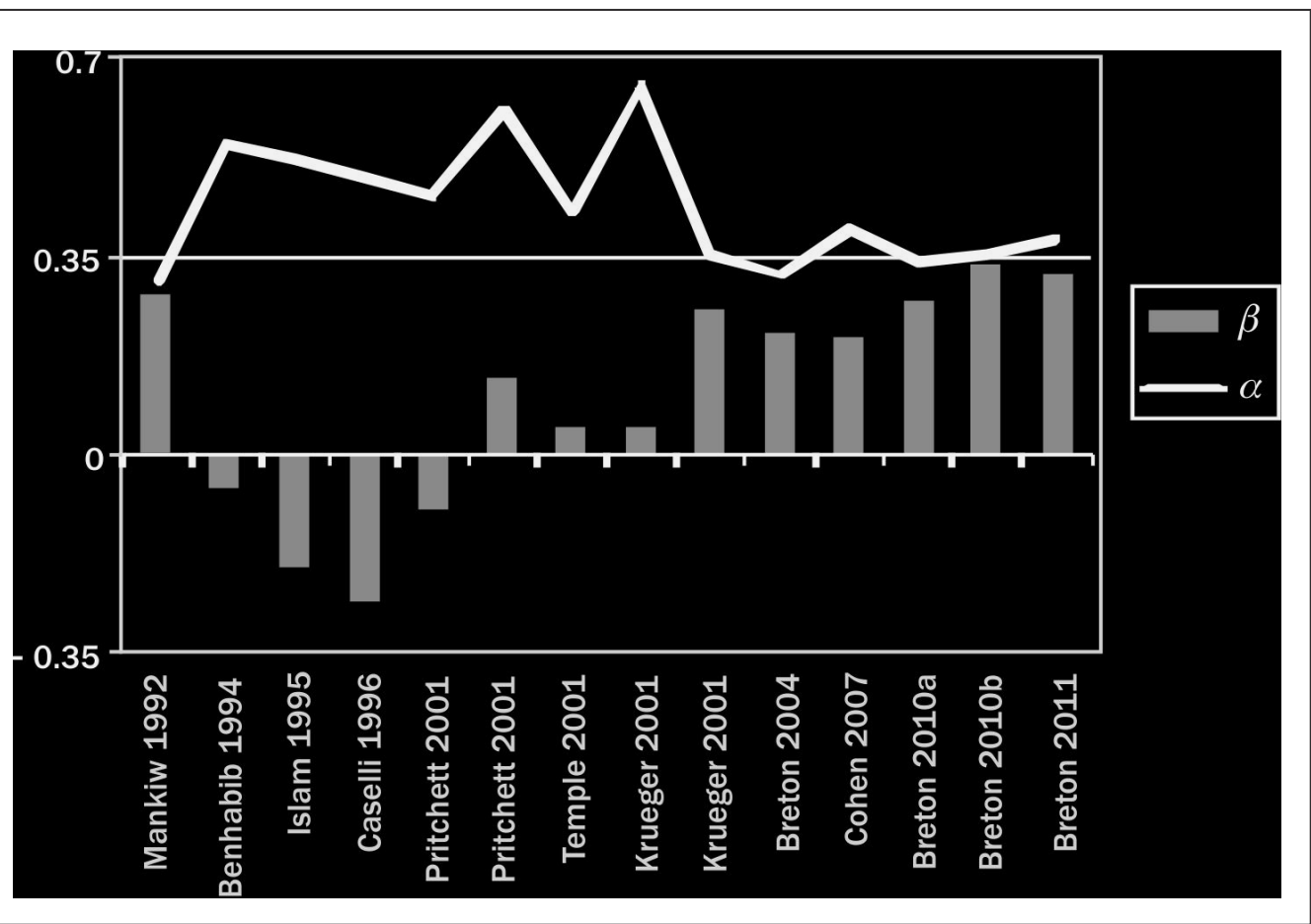

A major concern with all of these estimates of $\beta$ is whether they successfully control for the reverse effect of national income on schooling. As is well known, ordinary least squares (OLS) regression estimates show the correlation between the dependent and explanatory variables, but they do not show causality. Bils and Klenow (2000) argue that some of the estimates of $\beta$ in the literature are biased upward due to simultaneity bias resulting from the reverse effect of national income on schooling.

Some researchers have tried to control for this reverse effect by using lagged values of average schooling attainment as instruments for the current levels of schooling attainment. ${ }^{6}$ But Dougherty and Jimenez (1991) and Psacharopoulos and Layard (1979) have shown that the nation's earlier levels of schooling affect national income directly, so lagged attainment is not a valid instrument for human capital from schooling.

6 Ordinary least squares (OLS) regression examines the correlation between schooling and national income to create the estimates of $\beta$. This method yields biased estimates of $\beta$ if there is reverse causality from income to schooling. This bias can be controlled if the estimate of $\beta$ is developed using the correlation between schooling and a third variable, known as an instrument, that does not affect income directly. 
Does Investment in Schooling Raise National Income?

Evidence from Cross-Country Studies

THEODORE RICHARD BRETON

The 2007 and 2010 studies use different instruments. Cohen and Soto (2007) use a combination of lagged attainment and changes in lagged attainment as instruments to address this problem. Breton (2010a; 2010b) uses the Protestant share of the population 20 years earlier as an instrument for cumulative investment in schooling. This variable is highly correlated with levels of public schooling across and within countries. Concerns that this variable might not be a valid instrument because it could affect national income directly have been addressed in a recent study by Becker and Woessmann (2009). The use of these instruments for human capital in the latest studies provide some assurance that the estimated coefficients are measuring the effect of human capital on national output rather than the reverse effect of national income on investment in schooling. Breton's (2010b) estimates of $\alpha$ and $\beta$ are a revision of the Breton (2010a) estimates, based on a conceptuallysuperior methodology for the creation of the human capital and national income data. The human capital data are constructed using the perpetual inventory method documented in OECD (2001). These data include the implicit cost of financial capital during the period between the investment in education and the entry of the student into the work force. The national income data include an estimate of students' foregone earnings while they are in school, an element of national income that is not included in the national accounts (Kendrick, 1976). With these improvements in the cross-country data, arguably the implied value of $\beta=0.34$ documented in Breton (2010c) is the best estimate of the effect of human capital on national income to date.

\section{Policy Implications}

The empirical results in the latest cross-country studies indicate that if a nation wishes to increase national income per worker (or the rate of economic growth), one means to do so is to increase its investment in schooling. But one of the implications of the Cobb-Douglas production function is that the return on investment in any factor of production is subject to diminishing returns. The implication is that as nations raise their stock of schooling capital, national income increases at a decreasing rate. At some point the falling return on incremental investment in schooling makes further investment unattractive. So are nations overinvesting in schooling? This question can be answered using the empirical results from the cross-country studies.

A Cobb-Douglas production function has a very simple formula to estimate the marginal product of human capital from schooling (MPH). The MPH is the marginal change in 
national income from a marginal change in the nation's stock of human capital, holding the other factors of production constant:

(5) $\mathrm{MPH}=\delta \mathrm{Y} / \delta \mathrm{H}=\beta(\mathrm{Y} / \mathrm{H})=(\beta \mathrm{Y} / \mathrm{L}) /(\mathrm{H} / \mathrm{L})$

When calculated using national data, the MPH indicates the marginal return to the nation from incremental investment in schooling, and it includes both the direct and the external effects. Calculation of this rate for any country requires estimates of $\beta$, national income, and the national stock of human capital from schooling.

Breton's (2010c) data on these variables can be used to develop estimates of this marginal product for $\beta=0.34$. These estimates are shown in Figure 4 for 61 countries in the year 2000. They have the declining pattern expected with increases in human capital due to the phenomenon of diminishing returns, but some countries with very little schooling capital also have very low marginal rates.

\section{Figure 4}

Marginal Product of Human Capital from Schooling in 2000

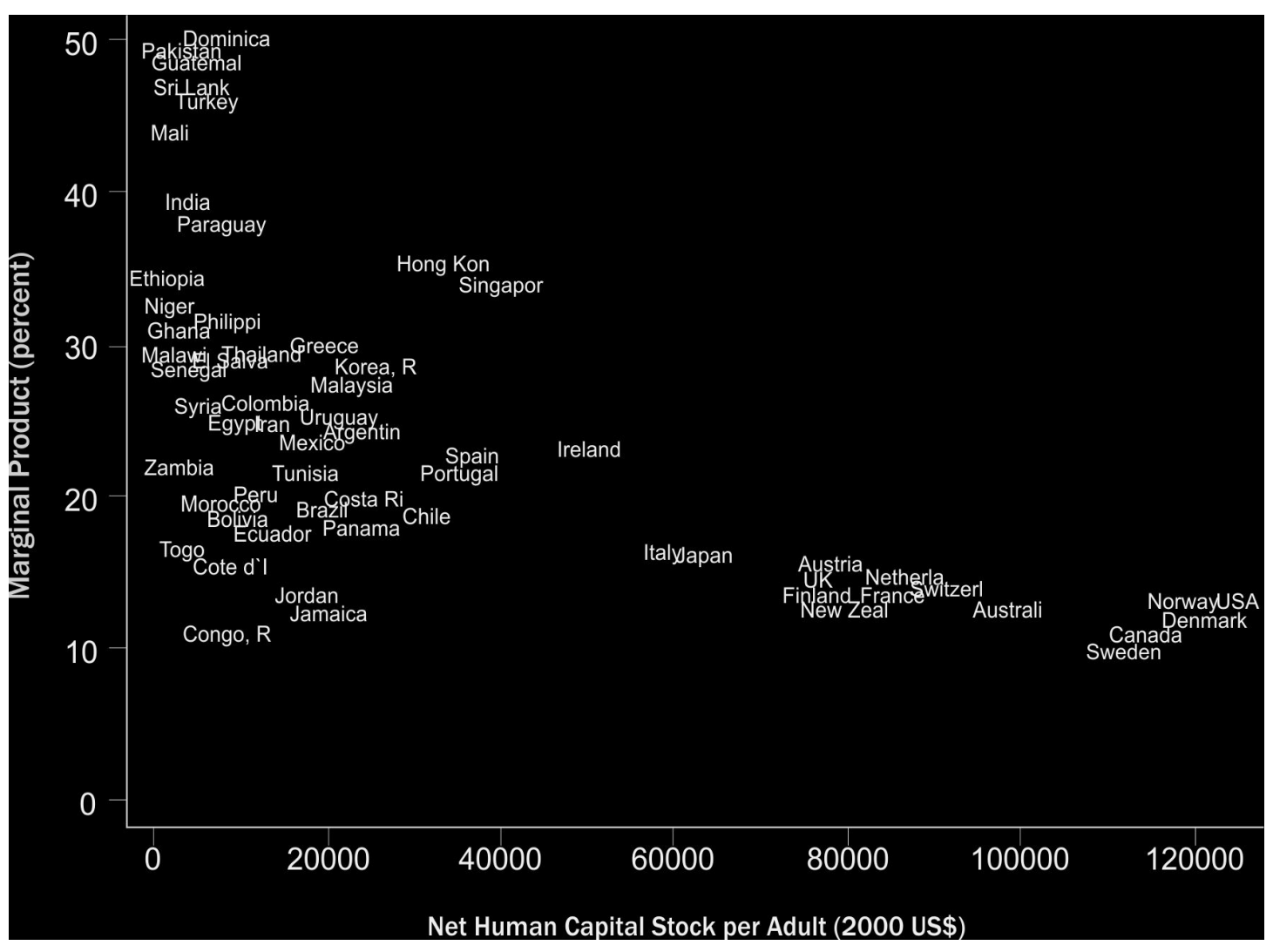




\section{4}

\section{Does Investment in Schooling Raise National Income? Evidence from Cross-Country Studies \\ THEODORE RICHARD BRETON}

The Republic of Congo, Jordan, and Jamaica are notable in the figure for their unexpectedly low marginal products of human capital. There are a variety of potential explanations for these low rates. The marginal product in a country could be low if national income is unusually low for reasons not related to schooling (e.g., due to a war or epidemic or unreported income from the underground economy), or if UNESCO's data on the country's public expenditures on schooling (as a share of national income) is too high, due to misreporting or to the illicit diversion of the funds intended for schooling to other uses. Another possible explanation is that the schooling process in these particular countries is less productive per dollar expended than average for countries with similar levels of cumulative investment in schooling.

As there may be data issues with the marginal product for any one country, particularly in poor countries, the important implication from these estimates is the pattern of the rates as a function of the national level of human capital. The pattern indicates that the marginal product of schooling is about 12 percent in countries with a high average level of schooling and about 25 percent in countries with a low average level of schooling. These estimates can be compared to Caselli and Freyer's (2007) estimates of the marginal product of reproducible physical capital, which in 1996 they found to average seven percent in poor countries and eight percent in rich countries. The implication of the rates shown in the figure is that the marginal product of human capital from schooling is about 50 percent higher than the marginal product of physical capital in rich countries and is (on average) about three times the marginal product of physical capital in poor countries.

It is important to realize that the rates in Figure 4 are marginal rates, which are different than average rates. The average rate of return measures the relationship between the historic investment in schooling and the share of national income currently accruing to workers, while the marginal product indicates the effect of incremental investment on national income. Because there are diminishing returns to investment in any one factor of production, the average national rates of return are considerably higher than the marginal products shown in Figure 4. It is also important to note that these marginal products do not provide any information about the marginal product of different types of schooling within a country, for example, preschool vs. university education. The rates shown in Figure 4 merely indicate the incremental national marginal product for the net human capital stock created from the historic mix of schooling in each country.

The clear policy implication of the evidence in the latest cross-country studies is that greater public investment in schooling is a cost-effective way to raise a poor country's 
level of income. Since the return on the investment occurs over the lifetime of the schooled worker, the income response is delayed. But the eventual effect of incremental schooling on national income in countries with a relatively low level of schooling is very substantial. These findings support an economic development policy that gives schooling a high priority for incremental public funding in poor countries.

The policy implications are a bit different for countries that already have high average levels of schooling. The marginal product of schooling in these countries is only slightly higher than the marginal product of physical capital. As the marginal product is the weighted average of the marginal products of all types of schooling, by implication the marginal product of some types of schooling is likely to be lower than the marginal cost of financial capital.

If the public objective is solely maximization of national income, public investment in schooling should be reallocated to those types of schooling with a higher marginal product. The analytic problem is that the marginal product that can be calculated for particular types of schooling within the country is the direct return to the schooled worker, which does not include the external return accruing to the nation. Given this dilemma, the best approach available to governments to optimize public investment in schooling may be to redirect public funds to those types of schooling whose direct marginal product is greatest and assume that these investments also have the highest national marginal product when the external effects are included.

\section{References}

Acemoglu, Daron, \& Angrist, Joshua. (2001). How Large Are Human Capital Externalities? Evidence from Compulsory Schooling Laws. NBER Macroeconomics Annual 2000. Cambridge: MIT Press.

Barro, Robert. J., \& Lee, Jong Wha. (1993). International Comparisons of Educational Attainment. Journal of Monetary Economics, 32(3), 363-394.

. (2001). International Comparisons of Educational Attainment: Updates and Implications. Oxford Economic Papers, (3), 541-63.

Basu, Kaushik, Narayan, Ambar, \& Ravallion, Martin. (2002). Is Literacy Shared Within Households? Theory and Evidence for Bangladesh. Labour Economics, 8, 649-665. 


\section{6}

Does Investment in Schooling Raise National Income?

Evidence from Cross-Country Studies

THEODORE RICHARD BRETON

Becker, Sascha O., \& Wössmann, Ludger. (2009). Was Weber Wrong? A Human capital Theory of Protestant Economic History. Quarterly Journal of Economics, 124(2), 531-596.

Benhabib, Jess, \& Spiegel, Mark M. (1994). The Role of Human Capital in Economic Development: Evidence from Aggregate Cross-Country Data. Journal of Monetary Economics, 34, 143-173.

Bernanke, Ben S., \& Gurkaynak, Refet S. (2001). Taking Mankiw, Romer, and Weil Seriously. NBER Macroeconomics Annual, 16, 11-57.

Bils, Mark, \& Klenow, Peter J., (2000). Does Schooling Cause Growth? American Economic Review, 90(5), 1160-1183.

Breton, Theodore R. (2004). Can Institutions or Education Explain World Poverty? An Augmented Solow Model Provides Some Insights. Journal of Socio-Economics, 33, 45-69

Breton, Theodore R. (2010a). Schooling and National Income: How Large are the Externalities? Education Economics, 18 (1), 67-92. . (2010b). Schooling and National Income: How Large are the Externalities? Corrected Estimates. Education Economics, 18(4), 455-456.

Breton, Theodore R. (2010c). Schooling and National Income: How Large are the Externalities? Revised Estimates. SSRN: http://ssrn.com/abstract=1669611

Breton, Theodore R., (2011). The Quality vs. the Quantity of Schooling: What Drives Economic Growth? Economics of Education Review, 30, 765-773.

Caselli, F., Esquivel, G., \& Lefort, F. (1996). Reopening the Convergence Debate: A New Look at Cross-Country Growth Empirics. Journal of Economic Growth, 1, 363-389.

Caselli, F. \& Feyrer, J. (2007). The Marginal Product of Capital. Quarterly Journal of Economics, 122(2), 535-568.

Chi, Wei. (2008). The role of human capital in China's economic development: Review and new evidence. China Economic Review, 19(i3), 421-436

Cohen, Daniel, \& Soto, Marcelo (2007). Growth and Human Capital: Good Data, Good Results. Journal of Economic Growth, 12(1), 51-76. 
Dinopoulos \& Thompson. (1999). Reassessing the Empirical Validity of the Human Capital-Augmented Neoclassical Growth Model. Journal of Evolutionary Economics, 9, 135-154.

Dougherty, Cristopher R. S., \& Jimenez, Emmanuel. (1991). The Specification of Earnings Functions: Tests and Implications. Economics of Education Review, 10 (2), 85-98.

FitzRoy, Felix \& Funke, Michael (1995). Capital-Skill Complementarity in West German Manufacturing. Empirical Economics, 20(4), 651-665.

Glewwe, Paul \& Jacoby, Hanan G. (2004). Economic Growth and the Demand for Education: Is There a Wealth Effect? Journal of Development Economics, 74(1), 33-51.

Grier, Robin. (2005). The Interaction of Human and Physical Capital Accumulation: Evidence from SubSaharan Africa. Kyklos, 58 (12), 195-211.

Heston, A., Summers, R., \& Aten, B. (2011). Penn World Table version 7.0, Center for International Comparisons of Production, Income and Prices at the University of Pennsylvania. Retrieve of: http://pwt.econ.upenn.edu/php_site/pwt_index.php

Islam, Nazrul. (1995). Growth Empirics: A Panel Data Approach. Quarterly Journal of Economics, 110(14), 1127-1170.

Kendrick, John W. (1976). The Formation and Stocks of Total Capital. New York: National Bureau of Economic Research.

Krueger, Alan B., \& Lindahl, Mikael. (2001). Education for Growth: Why and For Whom? Journal of Economic Literature, 39, 1101-1136.

Levine, Ross, \& Renelt, David. (1992). A Sensitivity Analysis of Cross-Country Growth Regressions. The American Economic Review, 82(14), 942-963.

Liu, Zhiqiang. (2007). The External Returns to Education: Evidence from Chinese Cities. Journal of Urban Economics, 61(3), 542-564.

Lopez-Bazo, Enrique, \& Moreno, Rosina. (2008). Does Human Capital Stimulate Investment in Physical Capital? Evidence from a Cost System Framework. Economic Modeling, 25(16), 1295-1305.

Lucas, Robert E. (1990). Why Doesn't Capital Flow from Rich to Poor Countries? American Economic Review, 80(2), 92-96. 


\section{8}

Does Investment in Schooling Raise National Income?

Evidence from Cross-Country Studies

THEODORE RICHARD BRETON

Maitra, Pushkar. (2003). Schooling and Educational Attainment: Evidence from Bangladesh. Education Economics, 11(2), 129-153.

Mankiw, N., Gregory. (1995). The Growth of Nations. Brookings Papers on Economic Activity, 1995(1), 275-310.

Mankiw, N. Gregory, Romer, David, \& Weil, David N. (1992). A Contribution to the Empirics of Economic Growth. Quarterly Journal of Economics, 107(2), 407-437.

Moretti, Enrico. (2004). Estimating the social return to higher education: evidence from longitudinal and repeated cross-sectional data. Journal of Econometrics, 121, 175212.

OECD. (2001). Measuring Capital: OECD Manual: Measurement of Capital Stocks, Consumption of Fixed Capital, and Capital Services, OECD Publication Services, www.SourceOECD.org

Pritchett, Lant. (2001). Where Has All the Education Gone? World Bank Economic Review, 15(3), 367-391.

Psacharopoulos, George \& Layard, Richard. (1979). Human Capital and Earnings: British Evidence and a Critique. Review of Economic Studies, 46(3), 485-503.

Psacharopoulos, George \& Patrinos, Harry. (2004). Returns to Investment in Education: A Further Update. Education Economics, 12(2), 111-134.

Rubinfeld, Daniel L., \& Shapiro, Perry. (1989). Micro-estimation of the Demand for Schooling: Evidence from Michigan and Massachussetts. Regional Science and Urban Economics, 19, 381-398.

Song, L., Appleton, S., \& Knight, J. (2006). Why Do Girls in Rural China Have Lower School Enrollment? World Development, 34(9), 1639-1653.

Summers, Robert \& Heston, Alan. (1991). The Penn World Table (Mark 5): An Expanded Set of International Comparisons 1950-1988. Quarterly Journal of Economics, 106(12), 327-368.

Temple, Jonathan R. W. (2001). Generalizations that Aren't? Evidence on Education and Growth. European Economic Review, 45, 905-918.

Yasar, Mahmut \& Morrison, Catherine. (s.d.). Capital-skill complementarity, productivity and wages: Evidence from plant level data for a developing country. Labour Economics, 15 (11), 1-17. 


\section{Appendix}

The effect of schooling on national income has been estimated using many different formulations of the Cobb-Douglas income model. Mankiw, Romer, and Weil (1992) and several other researchers estimated a steady-state version of this model. Cohen and Soto (2007) and Breton (2008) estimated reduced form versions of this model. In the alternative versions of these models, the estimated coefficients on the physical capital and schooling capital variables are not $\alpha$ and $\beta$, but the implied values of $\alpha$ and $\beta$ can be calculated from these coefficients. The form of the schooling and physical capital variable in the models, their estimated coefficients, and the implied values of $\alpha$ and $\beta$ are shown in Table A-1.

Table A-1

Values and Implied Values of $\alpha$ and $\beta$ in Cross-Country Studies

\begin{tabular}{|c|c|c|c|c|c|c|}
\hline \multirow{2}{*}{ Journal Article } & \multicolumn{3}{|c|}{ Physical Capital } & \multicolumn{3}{|c|}{ Human Capital } \\
\hline & Variable & Coef & $\alpha$ & Variable & Coef & $\beta$ \\
\hline $\begin{array}{l}\text { Mankiw, Romer, and } \\
\text { Weil (1992) }\end{array}$ & $\ln \left(\mathrm{I}_{\mathrm{k}} /(\mathrm{n}+\mathrm{g}+\mathrm{d})\right)$ & 0.69 & 0.31 & $\ln \left(I_{s} /(n+g+d)\right)$ & 0.66 & 0.28 \\
\hline $\begin{array}{l}\text { Benhabib and Spiegel } \\
\text { (1994) }\end{array}$ & $\ln (K / L)$ & & 0.55 & $\ln (H / L)$ & & -0.06 \\
\hline Islam (1995) & $\ln \left(I_{k} /(n+g+d)\right)$ & 1.08 & 0.52 & $\ln (H / L)$ & -0.42 & -0.20 \\
\hline $\begin{array}{l}\text { Caselli, Esquivel, and } \\
\text { LeFort (1996) }\end{array}$ & $\ln \left(\mathrm{I}_{\mathrm{k}} /(\mathrm{n}+\mathrm{g}+\mathrm{d})\right)$ & 0.64 & 0.49 & $\ln \left(I_{s} /(n+g+d)\right)$ & -0.34 & -0.26 \\
\hline \multirow{2}{*}{ Pritchett (2001) } & $\ln (K / L)$ & & 0.46 & $\ln (H / L)$ & & -0.09 \\
\hline & $\ln (K / L)$ & & 0.61 & $\ln (H / L)$ & & 0.14 \\
\hline Temple (2001) & $\ln (K / L)$ & & 0.43 & Attainment & 0.015 & 0.05 \\
\hline \multirow{2}{*}{$\begin{array}{l}\text { Krueger and Lindahl } \\
\text { (2001) }\end{array}$} & $\ln (K / L)$ & & 0.65 & Attainment & 0.015 & 0.05 \\
\hline & $\ln (K / L)$ & & 0.35 & Attainment & 0.083 & 0.26 \\
\hline Breton (2004) & $\ln \left(I_{k} /(n+g+d)\right)$ & 0.69 & 0.32 & $\ln \left(I_{s} /(n+g+d)\right)$ & 0.49 & 0.22 \\
\hline Cohen and Soto (2007) & $\ln (K / Y)$ & 0.68 & 0.40 & Attainment & 0.126 & 0.21 \\
\hline Breton (2010a) & $\ln (K / Y)$ & 0.89 & 0.34 & $\ln (H / Y)$ & 0.75 & 0.28 \\
\hline Breton (2010c) & $\operatorname{Ln}(K / L)$ & & 0.35 & $\operatorname{Ln}(\mathrm{H} / \mathrm{L})$ & & 0.34 \\
\hline Breton (2011) & $\operatorname{Ln}(K / Y)$ & 0.62 & 0.38 & Attainment & 0.19 & 0.33 \\
\hline
\end{tabular}


Does Investment in Schooling Raise National Income?

Evidence from Cross-Country Studies

THEODORE RICHARD BRETON

Recently Breton (2008)developed data on the cumulative investment in schooling for the population of working age in 61 countries. With these data it is possible to investigate directly the relationship between cumulative investment in schooling and Barro and Lee's (2001) data on average schooling attainment. This relationship, shown in Figure A-1 for 1990, clearly shows that cumulative investment in schooling has an exponential rather than a linear relationship to average schooling attainment. The model $\log (S / L)=y$ schooling attainment was estimated using Breton's estimates of cumulative investment as a proxy for $S / L$ to calculate the implied value of $\beta$ from estimates of $\gamma$ in the literature. Over the 1990-2000 period $y=0.30$ with the Barro and Lee (2001) data, and $y=0.36$ with the Cohen and Soto (2007) data.

\section{Figure A-1}

\section{Cumulative Investment in Schooling vs. Average Schooling Attainment in 1990}

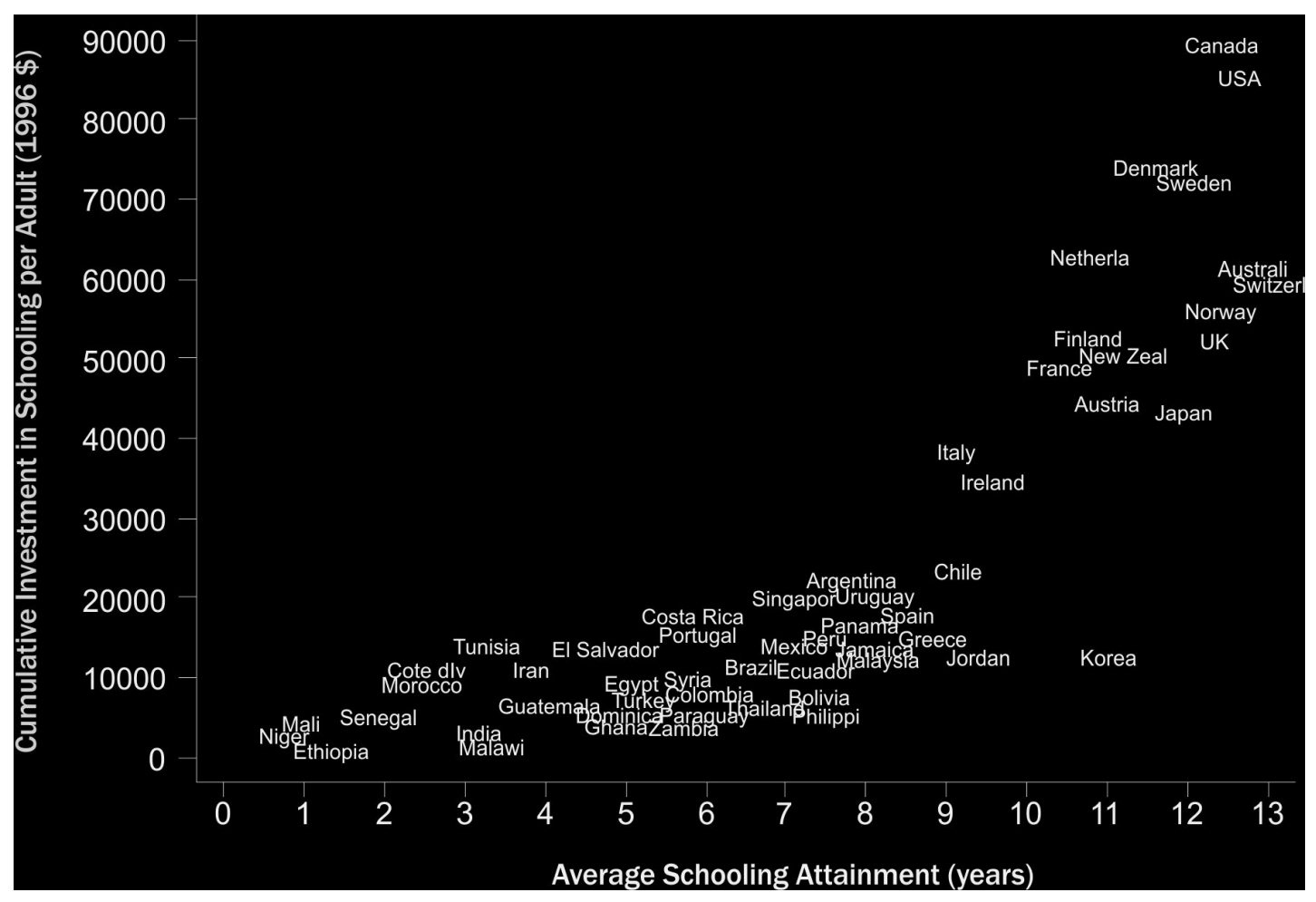

